部泙・紹介

かにし，東南アジア島嶼部への，リーバーマンのアプローチの適用可能性を示してい る(論文(9)。

ふたたびリーバーマンの議論にもどると, 上述の批判のほか, 国家（政治的・文化 的統合）を比較の単位とすることの妥当性，また，統合局面をとりあげることによっ て見落とされたものはないかなど個別的な実証の問題があるだろう。くわえて，歷史 社会学的手法を用いた比較分析の問題点として, 各地域の秋史のもつ個性や特色が, 偏差に還元されてしまうことも指摘できよう（本畫全体では他の執籍者による各論が, この点を補っている感がある)。

その一方で, リーバーマンの議論は, 例えば地域間の相互依存関係が紧密さを壇せ ば増すほど，ナショナル・アイデンティティーは強化されるという逆説を㬁き出し， 近代のナショナリズムとの接合可能性を述べる（両者が性格を異にするものであるこ とは認めているが）など，近世という時期にとどまらない問題提起を含んでいる。さ らに，93年の論文で示唆されていたが，考察範囲の設定に際し，東献アジアという料 組を前提としていない点も刺激的である。これは，アンソニー・リードのように，東 南アジアという地域的枠組を出発点にして，それを広げながら近世史を考えようとす る方向とは対照的にみえる。この意味でリーバーマン諭文は, 歴史的, 地域的なまと まりとして東南アジアを考えることに，新たな問いを発しているとも言えるだろう。 (連絡先：

千染大学文学部达学科)

O. W. Wolters

\title{
History, Culture, and Region in Southeast Asian Perspectives
}

revised edition, Ithaca : Cornell University Southeast Asia Program, 1999. 272p.

\section{桃木 至朗}

本書は，1982年にSingapore : Institute of Southeast Asian Studies から刊行され た同名の書物（以下，初版と呼ぶ）の増補版である。初版をそのまま再録（本留では pp.11-102）したあとに，6章に分かれたpostscripts（同pp.103-225）を加え，80年代 以降の（英語圏を中心とする）研究の進展を受けて初版を修正・補強すべき点, 网䦽 
する新しい論点などを縦横に論じている。巻末には新しいappendices, 文献目録, 索 引，地図などを付す。

初版では歷史的地域としての東南アジアの存在は自明の前提とはされず，地域を成 り立たせる共通性や枠組みは可能性として提起されたが，域内各地方ごとの多様性に ついての事例研究の積み重ねが訴えられていた。これに対し増補版のpostscriptsの冒 頭では，いまや地域としての「前近代東南アジア」が存在したことには確信をもつと 述べる。つづく前半の各章では，初版を有名にしたリーダーとしてのman of prowess，政体としてのマンタ゚ラなどの議論が再確認される。先史時代の諸コミュニティが 互いに孤立していたというイメージ，ベトナム異質論などは訂正され，無視されてい た火性とジェンダーや山地民の議論が補われて，マンダラは前近代東南アジア全域・ 全畤代をおおうものとされている（現代のグローバル化も，「ネオ・マンダラ時代」で はないかと示唆される)。マンダラの特徴としては, 自己を意味づけ世界のなかに位置 づけるための自己ヒンドゥー化（決定的だったのは「インド」でなく「ヒンドゥー」 だったとしてIndianizationの用語を批判)，王 (二文明を教える教師) と取り巻きたち が形成する「公的生活」，「(過去や未来でなく)いまへの関心」，王の威光を広げる「コ ミュニケーションの文化」, 水平的多元性や複合的で選択・交涉可能性の強い垂直化を 特徵とする「(ハイアラーキーとは違う) へテラーキー」, 外来の最新のものをつねに 追い求めるが「その場の対処」に終始して線的な発展＝集権化につながる構造変化は 起こさなかったこと，などが論じられる。先史時代と歴史時代の継続性については, セデスの「インド化」論だけでなく「マンダラの集権化」を説くハイアムの考古学を も批判し，セデスの「13紀の危機」論の核心をなすモン・クメールからタイへの勢 力交替については, W.オコナーの説を引いて突然で完全な断絶でなく, 元来の多言語 状沿のなかでの（もともとの住民たちの間での）ゆるやかなアイデンティティと生業 形態の変化と描きなおす。

postscriptsの後半で藷者は, 初版の後半で提起したがマンダラ諭ほど注目されなか った，外来文明のローカライゼーションとそれを通じたローカルな自己表現，その声 を䦌き取るためのソシュール的なテクスト研究などをより重視するよう主張する。前 近代怵南アジアの人々が「歴史」や「文学」として「なにを，どう書いたか」が，そ の多様性と共通性, ローカライゼーションのされ方, 彗き手の関心事, 作品の読まれ 厅と現帮に刘してもつう, などの角度から論じられる。postscript最後の章は, 冷戦終 結後の米国での地域研究切り捨ての動きと97年の東南アジア経済危機のなかでの, 東 南アジア史研㠰の生きる道を論じる。それは, 現在のグローバル化について地域研究 
と歷史研究がなければ理解も対処もできないことを示すことである，そのために研究 者は「ゲットー」に籠らず，他地域を専門とする研究者を魅きつけ共同させうるよう な研究の革新（それを自己の専門性を崩して他分野に手を出すことと証解してはいけ ない）が必要である，学部レベルでの教養教育（東南アジアを選択科目のひとつとす るのでなく，世界を教える各必修科目それぞれの内容の一部に東南アジアを組み込む こと）も重要である，その点で東南アジアは，マンダラの時代から「グローバル化と ローカライゼーション」を繰り返してきた地域として, 十分可能性をもつ, とりわけ テクスト研究は方法として可能性が大きい, というのが著者の結論である。

日本の「きまじめな」歴史研究者は，「この程度の漢文力でテクスト研究とは」「交 易の時代以降の近世世界がもたらした構造変化が軽視されている」東南アジアの共通 性やグローバル化を強調しベトナムも仲間に入れるなど, 現代の動きに密耆しすぎて いる」などと眉をひそめるかもしれない。だが評者は，1915年生まれの藷者がなお最 新の研究を大量に取り入れて初版を 2 倍半にふくらませる，あまつさえ 80 歳を過ぎた 男性研究者がジェンダーについておそらく初めて勉強し，まとまった論述をする (postscript IVのほか, 増補版のAppendices 2 ではべトナム陳朝の男女関係について 述べる）という「力」に驚嘆した。これは，そういうことを「強いる」アメリカの知 識人世界の力だろうか。学問がおかれた社会的状況が本質的に異なっているとも思わ れないなかで，いまだセデスの枠組みに縛られた書物も散見する(セデスから真に曼 け継ぐべきフランス式博学と文明論は抜きで?）日本の東南アジア前近代史学界は, どんな研究・教育・自己主張をすべきだろうか。

〔追記〕本稿脱稿後の2000年12月 5 日，ウォルタース教授が逝去した。われわれはまた 一人，植民地期東南アジアを直接体験した世代を失った。つつしルでご畕福を抢祈り したい。 